\title{
Bioethical aspects of basic research and medical applications of human stem cells
}

\author{
Manuel J. Santos (1)* \& Patricio Ventura-Juncá (2) \\ (1) Departamentos de Biología Celular y Molecular y Pediatría, Facultades de Ciencias Biológicas y Medicina and \\ (2) Centro de Bioética y Departamento de Pediatría, Facultad de Medicina, Pontificia Universidad Católica de Chile, Santiago, Chile.
}

\begin{abstract}
The new discoveries, the extraordinary dynamism in human stem cell (SC) research, and the great expectations of the benefits in clinical treatment of many diseases are on the edge of unparalleled advances in both: 1) the understanding of basic mechanisms of cell differentiation and development and 2) the translation from basic research to new clinical therapies. Human stem cells are obtained from different sources, such as embryo, fetal, and adult tissues, in vitro induction (iPS cells) or transdifferentiation. The evidence that these cells are pluripotent (or multipotent), meaning they have the ability to differentiate into all body tissues or tissues of the same lineage, raises the possibility that they could regenerate diseased or damaged tissue in diseases that until now have had no effective treatments. Human stem cell research and therapy raise important bioethical considerations because of the human nature of these cells and their peculiar characteristics. Here we discuss the bioethical aspects of basic human SC research and the conditions necessary for the translation of basic preclinical research into clinical use of SC.
\end{abstract}

Key words: Human Stem cells, Basic research, Bioethics; Clinical trials, translational research

\section{INTRODUCTION}

The production and use of human stem cells (SC), especially embryonic stem cells (ES) has attracted major scientific and public interest for two reasons: 1) From the scientific perspective, the evidence that these cells are pluripotent, meaning they have the ability to differentiate into all body tissues raises the possibility that they could regenerate diseased or damaged tissue in diseases that until now had no effective treatments (Andersson and Lendahl, 2009; Lindvall and Hyun, 2009; Riazi et al., 2009). This has resulted in high expectations in the media and public about treatments and eventual cures for a wide range of diseases, some of which have no effective treatment and mean painful situations for patients and their families, such as Alzheimer's disease, Parkinson's disease and Amyotrophic Lateral Sclerosis. Taking into consideration the rapid development of human SC research, there is a vast amount of information offered to patients, researchers, clinicians and members of the public. This information may be in many aspects questionable and presented in the media uncritically (Peddie et al., 2009). Sometimes scientists themselves, in interviews in the media contribute to expectations that are not consistent with the current state of SC use in human medical treatments (Choumerianou et al., 2008; Devereaux and Loring, 2010). 2) The other aspect discussed in the scientific literature and media is the ethical issues involved in how SC are obtained (for example from human embryos), how they are stored and how are they used in Medicine (Gómez-Lobo, 2004; Knoepffler, 2004).

\section{AIM OF THIS PAPER}

We discuss the bioethical aspects involved in basic SC research and the conditions necessary for the translation of preclinical basic research to the clinical use of SC. Furthermore, we deal with the sometimes thin line between legitimate medical innovation and offers of treatments that do not fulfill ethical and scientific standards but nevertheless excite anxious patients who find these treatments outside of regular medicine in what has been called "SC tourism"

\section{Definition and types of SC}

There are several types of human SC: embryonic stem cells (ESC), adult stem cells (ASC), induced pluripotent stem cells (iPS) and reprogrammed adult differentiated cells obtained by transdifferentiation.

All SC have the following characteristics: they are undifferentiated cells, i.e. they are not specialized or specific like the cells of different tissues; they can replicate themselves and they maintain their differentiation potential and may eventually regenerate various tissues (Álvarez et al., 2012).

The different types of SC differ in their origin, potential to generate various tissue and adverse effects when used in living organisms. Until recently only two types and ways to obtain stem cells were available. However, in 2006 Yamanaka and his group produced stem cells with embryonic characteristics by reprogramming differentiated cells from the skin. These stem cells were called induced pluripotent (iPS) cells (Takahashi and Yamanaka, 2006). More recently, direct transdifferentiation was obtained between two types of fully differentiated adult cells, thus bypassing the pluripotential state (Vierbuchen, 2010).

Embryonic stem cells (ESC)

In 1981, Evans and Martin successfully isolated and cultured in vitro the inner cell mass cells of mouse blastocyst. Since these

Abbreviations: SC: Stem Cells; ESC: Embryonic Stem Cells; ASC: Adult Stem Cells, FSC: Fetal Stem Cells; iPS: induced Pluripotent Stem cells

*Corresponding author: Manuel J. Santos, Departamentos de Biología Celular y Molecular y Pediatría, Facultades de Ciencias Biológicas y Medicina, Pontificia Universidad Católica de Chile, Casilla 114-D, Santiago, Chile. Tel (562) 3542835, Fax (562) 3542824, email: msantos@bio.puc.cl

Received: August 2, 2012 In Revised form: September 6, 2012. Accepted: September 11, 2012

** This review is based on a lecture offered at the 4th Annual World Congress of Regenerative Medicine and Stem Cell-2011, November 11-13, 2011, Beijing, China (abstr:041) 
cells can differentiate into various tissues of the body, they are called pluripotent. These in vitro cultured cells are called embryonic stem (Evans, 2011). This was a landmark advance in the understanding of development, tissue homeostasis and progress of Regenerative Medicine. Then, in 1998 inner mass cells from a human blastocyst were successfully cultured (Conaghan J, et al. 1998). The main feature of ESC cells is the ability to multiply indefinitely in vitro while maintaining their pluripotent nature and the ability to be biologically manipulated to differentiate into different cells of various tissues

\section{Adult Stem Cells (ASC)}

Adult stem cells are found in various tissues of an organism already formed and are able to form and regenerate cell lines from a particular tissue or tissues. This feature is called multipotency. ASC may be cultured in vitro but this is more difficult compared with multiplication of ESC (Schuijers and Clevers, 2012). The most studied and clinically used ASC are the hematopoietic and mesenchymal cells in bone marrow. It is also possible to obtain this type of cells from the cord blood (Rao et al., 2012) and from the umbilical cord (Hayward et al., 2012).

\section{Fetal Stem Cells (FSC)}

Pluripotent stem cells are also found in fetal tissues, called Fetal Stem Cells (Ryan et al., 2011). FSC have also been found recently in amniotic fluid (Antonucci et al., 2012).

Induced pluripotent stem (iPS) cells

Being able to reprogram somatic cells to the pluripotent state through the introduction of specific genes was considered almost impossible. However this was experimentally done and at present is an important way to obtain pluripotent stem cells. Research in the production and use of iPS cells has followed a rapid advance (Takashi and Yamanaka, 2006; Pietronave and Prat, 2012).

\section{Transdifferentiated cells}

Finally, we should mention that transdiferenciation of ASCs have been achieved (Liu and Chang, 2006) and more recently direct reprogramming of somatic cells in cardiomyocytes and nerve cells has been achieved. This is called direct transdifferentiation which bypasses the pluripotent state with the advantage of reducing the chances of producing tumors (Vierbuchen, 2010; Yang, 2011). Nevertheless total risks of this type of cells have not yet been resolved (Pournasr et al., 2012)

\section{BIOETHICAL ISSUES INVOLVED IN HUMAN STEM CELL BASIC RESEARCH}

Embryonic SC

The main ethical issue in obtaining human ESC is the use and destruction of human embryos. Decades of biology has shown that a new human organism begins at fertilization (Haeckel, 1912; Gilbert, 2006). By basic conceptual logic, a human organism is a human being. This is the today focus of discussion in terms of the anthropological ethics dealing with whether the human being at this stage of development is morally relevant and has the right to the inviolability of life at this period (Valenzuela, 2007; Zarcseczny and Caulfield, 2009; Santos and Ventura-Juncá, 2009; Shoemaker, 2010; VenturaJuncá and Santos, 2011). For some people, the personhood of a human embryo is reached at a later phase of development (for example at the 14th day of development), therefore the destruction of this so-called pre-embryo to obtain ESC form blastocysts (5-7th day) is morally acceptable (Wells, 1984).

Source of human embryos to obtain ESC

1. Embryos regularly obtained by IVF ("surplus" embryos): These are embryos obtained by IVF that are not used for implantation and are stored frozen at $-180^{\circ} \mathrm{C}$ (Brett $\mathrm{S}$ et al., 2009). Informed consent of the parents is required to use these embryos. Parents should understand that their embryos will be destroyed and parts will be used (inner cell mass) to obtain stem cells for research or in clinical applications. In some countries, such as the USA, a waiver of consent is permitted, thus allowing the use of embryos for research.

\section{Production of new human embryos}

2.1.Production of new human embryos from gamete donors: Human embryos may be created with oocytes and sperm from donors. If this is the case, obtaining Informed consent from donors should specify the terms of human embryo research. (National Academy of Sciences Guidelines for Human Embryonic Stem Cell Research, 2005, 2010; http:/ / www.nap.edu / catalog.php?record_id=12923\#description / access July 26, 2012). These guidelines imply that embryos are not people and not subject to respect as research subjects.

2.2. Production of new human embryos by Somatic Cell Nuclear Transfer: French et al (2008) have produced human embryos with somatic cell nuclear transfer. The authors published the development of human cloned blastocysts following somatic cell nuclear transfer with adult fibroblasts. Claims in Science in 2004 and 2005 by Hwang et al. to have cloned human embryos from healthy women and diseased patients, respectively, were proven to be fraudulent (Editorial Science, 2006). The production of human embryos by cloning represents a major ethical issue in that the production of cloned humans undermines human dignity by making a person into a product.

3. ESC produced by "parthenogenetic embryos": Parthenogenesis is a form of reproduction in which an unfertilized egg develops into a new individual. The first pESC lines derived from human parthenotes were obtained by Revazova et al. (2007) and Revazova et al. (2008). The main ethical question arising is whether a parthenote blastocyst is an altered human embryo or just a ball of cells without organization. This is a major anthropological question, with significant ethical consequences. The discussion continues and at the center is the question of the ontological status of parthenotes, which needs to be established before activated oocytes can be considered as an ethical source for pluripotent stem cells (Rao et al., 2008).

4. Production of ESC without destroying human embryos: The ethical objections in obtaining human ESC have encouraged efforts to obtain them with techniques that do not involve 
the destruction of human embryos. Several attempts have been proposed to circumvent to produce entities that are not considered human embryos but that could be capable of producing ESC. They have been complicated and most of them have not reached satisfactory results (White paper, 2005; Condic, 2008; Ventura-Juncá et al., 2009).

a) Altered Nuclear Transfer and Oocyte Assisted Reprogramming: Altered Nuclear Transfer is a modification of the nuclear transfer technique, with preemptive genetic and epigenetic modification of the nucleus of the somatic cell to be transferred (White Paper, 2005). When there is also an alteration of the oocyte cytoplasm before transfer is done, the technique is termed Altered Nuclear Transfer with Oocyte Assisted Reprogramming. The ethical hypothesis of those who defend this line of research is that the technique will result in a biological entity without the characteristics of an organism. The philosophical debate has centered on what are the necessary characteristics of a new organism and how can we differentiate a biological entity from an organism. Scientists and philosophers with the same anthropology regarding the human embryo, differ in their evaluation of this technique (Colombo, 2004; Austriaco, 2006; Hurlbut et al.,2006).

This strategy has been abandoned due to the complexity of the technique and doubts about its results from a scientific perspective, as well as ethical objections. As we stated in our previous paper in 2009 (Ventura-Juncá et al., 2009): “There is one published paper in which ESC lines were obtained with this strategy in mice. The technique consisted of silencing the $\mathrm{Cdx} 2$ gene from the nucleus of the somatic cell transferred to the oocyte (Meissner and Jaenisch, 2006 ). The cloned blastocysts were morphologically abnormal with no expression of the CDx2 gene. They lacked a functional trophoblast and failed to implant in foster mothers. Nonetheless, ESC lines were derived from these blastocysts. It is relevant that Meissner and Jaenisch, authors of this article, recognize that the ethical dilemma may not be resolved since the Cdx2deficient embryo appears to be normal in the first stages of development before the $\mathrm{Cdx} 2$ gene is expressed. In theory, the so-called biological entity by its defenders could be transformed into an embryo during the development to blastocyst by one single gene. It seems unlikely that the ontological condition of a biological organism could depend only on the simple silencing and activating of a gene. Thus, we could have new human beings that appear and disappears with this action alone. This demonstrates that the ethical aspects have not been solved and that the facts show that what are being produced are disabled embryos and not biological entities".

b) Human-animal chimeras: A chimera is a hybrid creature that is part human and part animal. Chinese scientists at the Shanghai Second Medical University in 2003 successfully fused human cells with rabbit eggs. The embryos were reportedly the first human-animal chimeras successfully created. They were allowed to develop for several days in a laboratory dish before the scientists destroyed the embryos to harvest their stem cells (reported by Mott, Maryann on January 25, 2005).
"Animal-Human Hybrids Spark Controversy". National Geographic News. http://news.nationalgeographic.com/ news / 2005/01/0125_050125_chimeras.html. (access July 26, 2012). But creating human-animal chimeras (named after a monster in Greek mythology that had a lion's head, a goat's body, and a serpent's tail) has raised ethical questions: What new sub-human combination could be produced and for what purpose? At what point would it be considered human? And what rights, if any, should it have? . Creating chimeras diminishes human dignity (Beca JP, 2007). In the UK, production of human-animal (cowsheep, etc) chimeras is allowed to obtain ESC, provided the chimeric embryos are destroyed by day $14^{\text {th }}$. (http:/ / www. hfea.gov.uk/docs/Hybrids_Chimera_review.pdf/ (access July 26, 2012)

\section{Fetal SC}

In countries where abortion is allowed, fetal stem cells are obtained from aborted fetuses. This is highly controversial, concerning mainly the ethical issue of abortion, i.e the termination of a human life (Lo and Parham, 2009).

\section{Adult SC}

Adult stem cells can be isolated from cord blood and umbilical cord, adult blood, adult bone marrow, or other adult tissues. Although their use does not pose the ethical issues raised by the use of human embryos, there are particular ethical issues common to all types of stem cells, especially related to the fact that after transplantation they remain in the host and may behave unpredictably in the human body (i.e. possible development of tumors). In addition, there are other relevant ethical issues such as the use of children (American Academy of Pediatrics, 2010), intellectual property and patents (Bahadur and Morrison, 2010), economic conflicts of interest (Caulfield, 2010) and how the information about the basic research and clinical applications are delivered to the public through the media (Lo et al., 2008; Sugerman, 2008, Lo and Parham, 2009). In relation to these specific matters, an adequate process of informed consent is a key feature. In terms of public and private cord SC banks, there is a debate over the type of information publicized in the media. Specifically, several private banks of umbilical stem cells can raise parents' expectations in ways not consistent with the findings of the scientific literature (Samuel et al., 2008). Specific regulations for public and private stem cell banks are needed, as well as clear information of their possible benefits (Smith, 2011).

\section{CLINICAL MEDICAL APPLICATION OF HUMAN STEM CELLS: TRANSLATIONAL MEDICINE}

\section{Embryonic Stem Cells}

The regenerative capacity of ESC has been tested in preclinical studies in vitro and in animals. The move to human clinical studies is challenged by unresolved ethical objections related to obtaining ESC from human embryos and the unresolved scientific problem concerning the production of tumors. In January 2009, the FDA approved the first Phase I clinical trial with differentiated cells obtained from ESC for treating paraplegics and in April 2011 for the treating Stargardt's 
Macular Dystrophy http:/ / www.clinicaltrials.gov (access July 26, 2012). Updated results have recently been published (Schwartz et al., 2012). On the other hand, the emblematic Geron embryonic stem cell clinical trial for spinal cord injury has been shut down (http:/ / www.nytimes.com/2011/11/15/business/ geron-is-shutting-down-its-stem-cell-clinical-trial.html). The production of ESC cell lines has aroused great expectations in both the scientific community and the public with the possibility that these cells could regenerate diseased or damaged tissues in several diseases that represent difficult and painful situations for patients and their families. Patients have unfounded expectations that SC therapy will improve their functioning (Daley, 2010). The major source of information on stem cells is the media rather than physicians. To reduce patients' exposure to inappropriate messages, doctors should make more effort to educate patients using mass media with accurate information (Kim et al., 2012)

\section{Adult Stem Cells}

The first marrow transplantation with multipotent stem cells from bone marrow, conducted in 1950 by Edward Thomas for treatment of leukemia opened a new way to regenerate tissues (Thomas, 2005). The progress of this procedure allowed its use in the treatment of other malignant diseases of the blood and is being studied for the use of other ASCs in various pathologies such as Multiple Sclerosis, Alzheimer's disease, Amyotrophic Lateral Sclerosis, heart tissue regeneration and Diabetes. The possibility to cure any sort of diseases by Regenerative Medicine (Andersson and Lendall, 2009) using ASC has also raised high expectations among the public and the media. More than hundreds worldwide clinical trials are being conducted or in progress with ASCs (http://clinicaltrials.gov (access July26, 2012). Apparently, ASCs produce less frequency of tumors and from the ethical point of view, human embryos are not destroyed to obtain them.

In Chile, treatment since 1995 has mainly involved proven ASC, especially those related to bone marrow transplantation for malignant blood diseases (Barriga $\mathrm{F}$ et al., 1995, Barriga et al., this issue). They are performed primarily in academic centers and approved by Ethical Research Committees. There are some experimental studies for the treatment of Dystrophic Epidermolysis Bullosa (Conget et al., 2010); Osteoarticular pediatric diseases (Norambuena et al., 2012) and Amyotrophic Lateral Sclerosis with small groups of patients (Soler et al., 2011).

\section{Fetal Stem Cells}

One phase I clinical trial is underway using neural stem cells derived from aborted fetuses for the treatment of Batten's disease (Lo and Perham, 2009). As mentioned above, from the ethical point of view this is highly controversial, due to the issue of abortion, i.e the termination of a human life. Several clinical trials are currently going on such as the use Human Fetal Liver Cell Transplantation in Chronic Liver Failure http: / / www.clinicaltrials.gov/ ct2 / show / NCT01013194?term =fetal+stem+cells\&rank $=1$ (access July 26, 2012) or and the use of human neural stem cells transplantation for the treatment of Amyotrophic Lateral Sclerosis (http://www.clinicaltrials. gov / ct2 / show / NCT01640067?term =fetal+stem+cells\&rank=4) (access July 26, 2012)
iPS cells

In the case of iPS, it should be noted that there are complex issues to resolve, such as ensuring complete multicellular reprogramming and stability, before iPS cells can be used in regular clinical treatment. If the iPS cells and transdifferentiated cells finally replace ESCs, broad ethical and scientific consensus could be reached among researchers with different anthropological and ethical positions regarding the respect due to the human embryo. For all of those who recognize a human being in the human embryo, with the dignity and rights of a member of the human family, the iPS cells and transdifferentiated cells is a major line of research that merits significant support and work. But one should be cautious in creating too much expectation about the potential benefits of the use of these cells (Pietronave and Prat, 2012).

\section{BIOETHICAL ISSUES IN THE MEDICAL USE OF HUMAN STEM} CELLS

The anthropological debate on the status of the human embryo is and has been central to the case of ESC. But there are other ethical issues common to all SC, which are related to translating biotechnological progress to clinical use. These are becoming increasingly important. (Lo et al., 2008; Lo and Parham L, 2009; Hyun, 2010a,b). These issues, though common to all clinical research, have specific implications and consequences in the case of SC that require special attention. These include, among others, informed consent, (Lo et al., 2008); the use of children as donors (American Academy of Pediatrics Committee on Bioethics, 2010); intellectual property and the need for regulation of any patents derived from research with SC (Simon et al., 2010; Bahadur and Morrison; 2010), financial conflicts of interest arising out of the market potential of SC, which can influence the direction of research, public information and equitable access to treatment (Lanoszka, 2003; Caulfield, 2010). Developing countries in this regard are particularly vulnerable (Pratt and Loff, 2010). Unlike a new drug, SC transplantation remains in the organism and its behavior is still in many respects unpredictable. In addition to these issues, there is the area of ethical and scientific implications of storing cord blood in private banks (family) and advertising and the information given to parents about their potential benefits (Onisto et al., 2011; cryopreservation in Chile: http: / / www.cryo-cell.cl/ access July, 2012; http: / / www. vidacel.cl/ access July, 2012). One particular bioethical issue common to the use of any SC is how to inform the public about the real contribution of SC to treat diseases, so the public may make better and more informed decisions. This poses a major responsibility for doctors and researchers to provide such information (Peddie et al., 2009).

Reasonable expectations of Regenerative Medicine with SC: The danger of transforming hope into hype

Regenerative Medicine based on SC therapy can dramatically change Medicine (Andersson and Lendhall, 2009). This hope has solid foundations in the substantial preclinical research in the laboratory and in animals with various types of SC, as well as results of some clinical ASC treatments. However, there are still serious unresolved scientific problems to overcome before the move to clinical use. These are mainly related to the basic 
safety needed for any new treatment (Hyun et al., 2008). The problem of tumor production is one of the most relevant. The International Society for Stem Cell Research (ISSCR) (http:// www.isscr.org (access July 26, 2012) has stated that so far, the only therapy with SC incorporated as a standard medical treatment is the use of ASC for a few number of diseases with such as hematopoietic ASC transplantation for leukemia and other blood diseases, epithelial stem cells to treat burns and some problems with the cornea (Rama et al., 2010). Bone marrow transplantation has certainly brought a qualitative improvement of great importance in medicine in recent decades (Perry and Linch, 1996). The number of worldwide ongoing clinical trials with ASC exceeds hundreds. In the case of human ESC, only one clinical trail is currently underway (Schwartz et al., 2012). In the case of iPS cells, there are currently more than 10 ongoing clinical trials but no treatment has been approved for regular clinical use. It is highly likely that the dynamics of research in this field can reach clinically validated treatments in several other areas of medicine with different types of SC.

However, public perception, the media and many patients have expectations beyond the current development of Regenerative Medicine with SC. The anguish of patients and sometimes the enthusiasm of doctors and researchers can obscure the fact that there is a long road ahead for preclinical research before safe clinical application. Scientists have noted that it is important that the great expectations raised for years with gene therapy and the very limited results may not be repeated with SC therapy (Verma, 1994; Couzin and Kaiser, 2005; Rosenecker, 2010).

In summary, the translation from basic research to clinical practice in the case of SC raises particular ethical and scientific issues that currently concern both scientists and bioethicists.

\section{Clinical trials, and innovation in Medicine}

The clinical trial path. There is consensus among scientists and bioethicists that generally the safest and most responsible route for approval of new treatments is the process of approved clinical trial protocols. The experience of decades has shown the importance of this route, especially in the case of new drugs (Meadows, 2001), which includes first preclinical studies and then a sequence of clinical phases intended to test the safety and benefits of the new treatment known as phase I-II-III and IV. The rigorousness of this process includes scientific and ethical aspects The protocols must be approved by competent scientific and bioethical authorities. This has meant a solid advance in medicine and patient protection, becoming the paradigm of clinical research.

The path of innovation in Medicine. Beyond clinical trials. It is evident that not all medical progress has been made through the clinical trial model. This is a discussion that covers various areas of Medicine that has particular ethical dimensions (Agich, 2001). Progress has also been achieved by medical innovation. The classic example is Surgery. There are numerous surgical procedures that were developed outside the clinical trail scheme for reasons of their own development. Examples are laparoscopy and cardiac transplantation, among others (Cosgrove, 2008). Something similar has happened in other areas of Medicine, especially in Pediatrics and Neonatology This route is not without risks (James and Lanman, 1976;
Duc, 1995). There are treatments that have been incorporated into regular use in the clinic, however when they have undergone clinical trials they have lost their validity, due to the contribution of evidence-based Medicine. Thus, medical doctors and patients should be aware of the uncertainties and risks involved in this course of action (Mcculloch et al., 2009). The issue of medical innovation out of the process of clinical research regularly, is of special interest in the case of SC and highly controversial (Hyun, 2010; Martell et al., 2010).

Ethical research policy and ethics of caring for the sick. The purpose of clinical trials is to produce a general knowledge for the use of new treatments with proven effectiveness and safety. The good of an individual patient is not the primary objective. In the case of innovative treatments that have not been tested by clinical research protocols, the perspective is different. They are covered by the field of ethics of the patient care aimed at the welfare of the individual patient. The ethics of clinical research does not have the same parameters as the ethics of the individual patient care. While there is always a risk versus benefit assessment, it requires a particular informed consent because the purpose is different.

In an innovative treatment the goal is the good of the patient without knowing the outcome for certain. This requires a particular form of informed consent to guarantee the security of the patients involved to be consistent with the intended purpose. The experimental treatment plan should be reviewed by qualified peers on scientific and ethical grounds. The results should be reported in scientific journals. Fulfilling these conditions, as expressed by Lindvall and Hyun in 2009, innovative treatment outside the framework of clinical trials may be acceptable from a scientific and ethical perspective. These treatments should be reserved for severely ill patients who have no good treatment options. These patients are usually anxious and more interested in getting better and surviving than in expanding medical knowledge. They and their physicians should be clearly informed, given that SC will remain in the body and behave unpredictably. In order to warrant safety in innovative SC treatment more ethical considerations should be taken care of, such as clarifying the types of patients who qualify for them, maintaining adequate monitoring, taking into account the lack of evaluation of the placebo effect and giving consideration to the route for clinical trials if the gains are positive for a small group of patients (Cohen and Cohen, 2010b). Although medical innovation in the treatment of patients has made significant progress, major disasters have also occurred in Medicine and Surgery in the past (James and Lanman, 1976; Duc, 1995; Mello et al., 2001).

\section{Stem Cell Tourism}

The emergence of clinics worldwide that offer treatment with SC: The high expectations created by the potential therapeutic benefits of SC have had two interrelated effects. On the one hand, patients with severe or untreated diseases are eager to access SC treatment of diseases for which conventional treatment are ineffective (Jawad et al., 2012). At the same time, there is an increasing number of unregulated clinics worldwide that offer SC treatment for various diseases (Kiatpongsan and Sipp, 2009). As a result, patients suffering from untreatable or incurable diseases are the subject to unrealistic promises, unpredictable risks, misinformation, and eventual economic 
exploitation (Taylor et al., 2010). This is called "stem cell tourism"(Carrera and Bridges, 2006; Chandler, 2010; Cohen, 2010; Crozier and Thomsen, 2010; Lunt and Carrera, 2010; Murdoch and Scott, 2010; Master and Resnick, 2011; Jawad et al., 2012). The stem cell tourism differs from the situation in which patients with serious illnesses, travel to qualified centers in other countries to get a better treatment or more experience. We agree with Mainil et al (2012) that a better alternative terminology for this latter procedure is "'transnational health care", understood as a "context-controlled and coordinated network of health services", which is rather different from the concept of stem cell tourism.

The emergence of the stem cell tourism clinics has raised concerns among scientists and bioethicists who raise serious scientific and ethical issues underlying this situation about the prestige of SC research and patient safety (Nelson, 2008; Gunter et al., 2010). In 2006 an article in Science reported there were nine research institutions around the world offering SC treatment for a range of very different diseases, mainly neurological disorders (Parkinson's, Amyotrophic Lateral Sclerosis, Spinal Cord injuries, Autism, Depression), but the range included Myocardial Infarction, Diabetes, AIDS, Cancer and even infertility (Enserink, 2006). The SC used were mainly ASC from the patient's own cord blood or from abortions (fetal). The cost of these treatments was about U.S. \$20,000, excluding travel expenses and accommodations. The number of patients being treated adds up to many thousands and with results that were, in some cases, dramatic, according to the clinics involved. In 2008, Lau et al. studied 19 clinical treatment offers, the way that the treatments are presented to the public and the clinical evidence for the treatments offered. The results showed that treatment offerings are varied and optimistically presented. However, there was no precise information on the types of SC used, their origin and how they were administered and there was no indication if these treatments had been evaluated by experts. The information given to patients over the Internet was incomplete and could have raised public expectations without solid foundations. All clinics reported an improvement in treated patients, but without statistical support to evaluate the results. There was no clear mention of the risks. Only a few clinics mentioned problems associated with the procedure. The authors warned that the overall results do not imply the clinical assessment of each individual, because there was no access to personal information received by patients or adverse or beneficial results.

The number of these clinics is increasing (Dolgin, 2010; Ryan et al., 2010). They are found in Russia, Santo Domingo, Barbados, China and India, where there are fewer regulations to control such treatments (Pepper, 2010). But there are also clinics in countries with greater safeguards, like Holland and Germany. In the mainstream print media, offers are presented optimistically, influencing the perceptions of patients (Zarzeczny et al., 2010). China is the subject of special attention because of the high number of clinics and patients recruited. It is estimated that there are about 100 laboratories dealing with SC techniques and at least three clinics that offer treatment. By 2009, it was It was estimated that about 6500 patients would receive treatment in two of the largest clinics in China, many of them from other countries (Mcmahon and Thorsteinsdóttir, 2010a). The lack of control over the quality of the treatments offered led the government to implement some regulations, which have been considered inadequate and poorly enforced (Cyranoski, 2009; Nature Editorial, 2010). Cohen and Cohen (2010a) analyzed the situation in Russia and India, where there are similar situations. The way to reach a large number of patients is primarily through the Internet. This avoids regulations in some countries that affect advertising media such as television and brochures. Reports of problems with unregulated SC treatment corroborate the risks of these offers to patients and challenge the prestige of SC research and clinical use. For example, there is a report of a child in Moscow, Russia, with a brain tumor after being injected with fetal neural stem cells in the cerebrospinal fluid (Amariglio, 2009; Macready, 2009). In Thailand a child developed a special form of tumor after a clinic injected autologous ASC to the kidney (Thirabanjasak et al., 2010; Cyranoski, 2010a). In Korea, two patients died after SC treatment (Cyranoski, 2010b) and in Germany a child with Cerebral Palsy died after SC was injected in the brain (Tuffs, 2010).

\section{The urgency to establish regulations}

The situation described above has prompted the scientific community and bioethicists to seek regulatory criteria and requirements for information to protect patients and their relatives (Cohen and Cohen, 2010b). For this to be effective in an increasingly globalized and interconnected world, it is necessary that there be international agreements among nations (Mason and Manzotti, 2010, Schalev, 2010).

Recommendations for clinical trials: In 2008 a group of experts at the request of the president of the International Society for Stem Cell Research (ISSCR) published the guidelines for the translation from preclinical research to clinical application (International Society for Stem Cell Research: http://www.isscr.org/ access July 26, 2012). Hyun et al. (2008), commenting on these guidelines, state that SC clinical research involves specific aspects that need to be treated carefully. In agreement with other researchers (Lo and Parham, 2009; Lo et al., 2008), they emphasize the following: the review of treatment protocols by SC experts; the need to clearly define the origin, quality and handling of the SC used; the informed consent process requires additional aspects compared to the one generally used in scientific research, such as information regarding scientific and ethical aspects of particular relevance, especially when they involved the destruction of embryos, the risks involved with different types of SC and the possibility of adverse effects, and the lack of knowledge about long-term effects, etc., regular monitoring of the participants in research to ensure their welfare,transparency in communicating the positive and negative outcomes, and adverse effects and social justice in access to treatment.

Recommendations for treatments of medical innovation beyond clinical trials: The ISSCR guidelines assume that if certain requirements are met treatments beyond clinical trials can be ethically and scientifically valid for application to a small group of patients with severe and intractable diseases http: / / www.isscr.org/ GuidelinesforClinicalTranslation/ 2480. htm (access July 26, 2012). Given the novelty of the SC, they can have unpredictable behavior that must be considered by doctors and informed patients. The summary of these requirements is: There must be a written protocol of the 
procedure (including scientific consistency for use with a particular patient or small group; justify its use as opposed to other possible treatments, characterization of the SCs to be used: origin, type, in vitro manipulation, specify method of administration; follow-up plan and monitoring to assess effects and effectiveness); written approval by competent reviewers not involved in the investigation; medical institution and the doctor performing the treatment should take responsibility for this; the institution must have competent personnel and adequate facilities; informed consent must be complete and transparent (It should be determined if the patient has understood that it is an unproven intervention and the possible risks and benefits); regular medical checkups and plan for possible adverse effects; the purpose of the research in contributing to SC research and the generalization of the results should be made explicit by those responsible for the research (this includes: systematic evaluation of the result, communication of results, plan to move to clinical trials in adequate time).

Increased offers of SC treatments in clinics in several countries around the world moved the ISSCR in 2010 to publish the Patient Handbook on Stem Cell Therapies, which is available in several languages / http://www.isscr.org/The_ Patient_Handbook.htm; access July 26, 2012).

The debate about regulation and patients' autonomy: This issue is still debated. The International Cellular Medicine Society (ICMS) is an organization formed by scientists, doctors and patient, with the aim of cooperating in informing and educating physicians and patients about the use of and advancement in SCs. The ICMS has a record of the clinics that offer treatment and also provides guidance on quality and safety (http://www.cellmedicinesociety.org/ access July 26, 2012). According to the ICMS, the ISSCR guidelines are more oriented to research and interfere with the autonomy of patients and physicians to use well-regulated SC beyond clinical trials. The debate continues through open letters on the position by both institutions (Audley, 2011; Sipp, 2011).

Finally, we must consider the issue of doctors who use drugs that are experimental or that are used for treatments which they have not been approved for (Okie, 2006; Radley et al., 2006; Lat et al., 2011). This is a relatively common practice. However, it is essential to consider differences between SC and drugs. SC will live for a long time and can affect the patient with unexpected responses and changes depending on environmental signals and intrinsic properties (Ginis and Rao, 2003). The use of SC by some clinics has provoked the intervention of the Federal Drug Administration (FDA) (Cyranoski, 2010). These clinics have defended their position and claim to follow the ISCM guidelines. An article in Nature in 2010 mentioned the lawsuit filed by the FDA against a clinic that was using SC for the orthopedic regeneration. Its medical director C. Centeno defended his position and reported his results in scientific journals (Centeno et al., 2010). Some policies have been established concerning the information provided by SC clinics. According to these policies, there is arguably an ethical duty to provide potential clients of the clinics with the best available information about the risks and benefits of what is essentially an experimental treatment.

Patients affected by untreatable diseases often turn to alternative or natural Medicine, which in many cases does not have a scientific basis. Nobody considers that they do not have the right to do this. But, is this comparable to the case of SC tourism?. We think not. Stem cells remain in the patient's body and can have unexpected harmful effects as in the cases cited above.

\section{CONCLUSIONS}

The ethical aspects of research and clinical application of SC are very important. Initially the main ethical debate related to the moral status of the human embryo. While this remains an important issue, new scientific developments, and especially the transfer to clinical application of SC, have raised additional ethical challenges.

The hope of curing various diseases has produced disproportionate excitement in the public that does not correlate with the current status of the clinical use of SC. The existence of unregulated clinics that offer SC treatment, in most cases with serious scientific and ethical shortcomings, has led to hundreds of anxious patients going to these clinics with great expectations and at great cost. Moreover, this jeopardizes the prestige of research in this field.

The scientific community and bioethicists have responded to this situation by providing guidelines for the licit translation from the pre-clinical research to the clinic and providing patients with information on clinics offering SC treatments and how to evaluate the decision to go to them.

We also addressed the issue of innovation and medical progress beyond clinical trials and the scientific and ethical requirements for these exceptional cases. It is not easy to make a clear separation between what is medical tourism and accepted clinical innovation according to precise parameters.

In the future it will be necessary to establish global guidelines and regulations implying an agreement among countries to effectively protect patients and ensure the proper use of the amazing advances expected with SC treatment and research for the sake of science and of all patients considering the requirements of social justice worldwide.

\section{AKNOWLEDGMENTS}

This work was supported by the VII Concurso de Investigación para Académicos. UC 2009-2010. “POR UN AUTÉNTICO DESARROLLO DEL HOMBRE", Pontificia Universidad Católica de Chile. Vicerrectoría Adjunta de Investigación y Doctorado. Project \# 864-47.

\section{REFERENCES}

AGICH GJ (2001) Ethics and innovation in medicine. J Med Ethics. 27(5):295-296. ÁLVAREZ CV, GARCÍA-LAVANDEIRA M, GARCÍA-RENDUELES ME DIAZ-RODRÍGUEZ E, GARCÍA-RENDUELES AR, PÉREZ-ROMERO S, VILA T, RODRIGUES JS, LEAR P, BRAVO SB (2012) Defining stem celltypes: understanding the therapeutic potential of ESC, ASC and iPS. J Mol Endocrinol [Epub ahead of print] Jul 19.

AMARIGLIO N, HIRSHBERG A, SCHEITHAUER BW, COHEN $\mathrm{Y}$ LOEWENTHAL R, TRAKHTENBROT L, PAZ N, KOREN-MICHOWITZ M, WALDMAN D, LEIDER-TREJO L, TOREN A, CONSTANTINI S, RECHAVI G. (2009) Donor-derived brain tumor following neural stem cell transplantation in an ataxia telangiectasia patient. PLoS Med. 6(2):e1000029.

AMERICAN ACADEMY OF PEDIATRICS COMMITTEE ON BIOETHICS (2010) Children as hematopoietic stem cell donors. Pediatrics 214:392404.

ANDERSSON ER, LENDAHL U (2009) Regenerative medicine: a overview. Intern Med 2009 266:303-310. 
ANTONUCCI I, PANTALONE A, TETE S, SALINI V, BORLONGAN CV, HESS D, STUPPIA L (2012) Amniotic fluid stem cells: a promising therapeutic resource for cell-based regenerative therapy. Curr Pharm Des 18:1846-1863.

AUDLEY D (2011) Open letter. Access July 25, 2012 http://www. cellmedicinesociety.org/attachments / 233_Open\%20Letter\%20To\%20 Stem\%20Cell\%20Clinics\%20v2.pdf Access July 25, 2012.

AUSTRIACO NPG (2006) The Moral Case for ANT-Derived Pluripotent Stem Cell Lines. National Catholic Bioethics Quarterly 6:517-537.

BAHADUR G, MORRISON M (2010) Patenting human pluripotent cells: balancing commercial, academic and ethical interests. Hum Reprod. 25:14-21.

BARRIGA F, BERTÍN P, BAEZA R, PEREIRA J, SCHWARTZMANN L, OLIVA J, OCQUETEAU M, SAPUNAR F, DUHALDE M, LIRA P, ET AL. (1995) Allogenic bone marrow transplantation in the treatment of malignant hematologic disease. Rev Med Chil. 123:605-611.

BECA JP (2007) Hybrid embryos as a source of embrionic stem cells. Rev Méd Chile 135:1367-1369.

BRETT S, LIVIE M, THOMAS G, MCCONNELL A, RAJKHOWA M (2009) Report on the donation of supernumerary embryos from fresh IVF and ICSI treatment cycles for human stem cell research. Hum Fertil 12:34-39.

CARRERA P, BRIDGES JFP (2006) Globalization and healthcare: understanding health and medical tourism. Expert Rev Pharmacoecon Outcomes Res 6:447-454.

CAULFIELD T (2010) Stem cell research and economic promises. J Law Med Ethics. 38(2):303-313.

CENTENO CJ, SCHULTZ JR, CHEEVER M, ROBINSON B, FREEMAN M, MARASCO W (2010) Safety and complications reporting on the re-implantation of culture-expanded mesenchymal stem cells using autologous platelet lysate technique. Curr Stem Cell Res Ther 5:81-93.

CHANDLER J (2010) Stem cell tourism: doctors' duties to minors and other incompetent patients. Am J Bioeth 10:27-28.

CHOUMERIANOU DM, DIMITRIOU H, KALMANTI M (2008) Stem cells: promises versus limitations. Tissue Eng Part B Rev 14:53-60.

COHEN CB, COHEN PJ (2010a) International stem cell tourism and the need for effective regulation. Part I: Stem cell tourism in Russia and India: clinical research, innovative treatment, or unproven hype? Kennedy Inst Ethics J 20:27-49.

COHEN CB, COHEN PJ (2010b) International stem cell tourism and the need for effective regulation. Part II: Developing sound oversight measures and effective patient support. Kennedy Inst Ethics J 20:207-230.

COHEN IG (2010) Medical tourism: the view from ten thousand feet. Hastings Cent Rep 40:11-12.

COLOMBO R (2004) Altered Nuclear Transfer as an Alternative Way to Human Embryonic Stem Cells: Biological and Moral Notes. Communion 31: 645-648.

Comment (2011) Pediatr Blood Cancer 56:1009-1012.

CONAGHAN J, HARDY K, LEESE HJ, WINSTON RM, HANDYSIDE AH (1998) Culture of human preimplantation embryos to the blastocyst stage: a comparison of 3 media. Int J Dev Biol 42:885-893.

CONDIC ML (2008) Alternative sources of pluripotent stem cells: altered nuclear transfer. Cell Prolif. 41 (Suppl 1):7-19.

CONGET P, RODRÍGUEZ F, KRAMER S, ALLERS C, SIMON V, PALISSON F, GONZÁLEZ S, YUBERO MJ (2010) Replenishment of type VII collagen and re-epithelialization of chronically ulcerated skin after intradermal administration of allogeneic mesenchymal stromal cells in two patients with recessive dystrophic epidermolysis bullosa. Cytotherapy. 12:429-431.

COSGROVE DM (2008) Ethics in surgical innovation: vigorous discussion will foster future progress. Cleve Clin J Med 75 (Suppl 6):S6.

COUZIN J, KAISER J (2005) Gene therapy. As Gelsinger case ends, gene therapy suffers another blow. Science 307:1028.

CROZIER GK, THOMSEN K (2010) Stem cell tourism and the role of health professional organizations. Am J Bioeth. 10:36-38.

CYRANOSKI D (2009) Stem-Cell Therapy Faces More Scrutiny in China. Nature 459:146-147.

CYRANOSKI D (2010a) Strange lesions after stem-cell therapy. Nature. 465:997.

CYRANOSKI D (2010b) Korean deaths spark inquiry. Nature.468:485.

CYRANOSKI D (2010c) FDA challenges stem-cell clinic. Nature 466:909.

DALEY GQ (2010) Stem cells: roadmap to the clinic. J Clin Invest. 120:8-10.

DEVEREAUX M, LORING JF (2010) Growth of an industry: how U.S. scientists and clinicians have enabled stem cell tourism. Am J Bioeth. 10:45-46.

DOLGIN E (2010). Survey details stem cell clinics ahead of regulatory approval. Nat Med.16:495.
DUC G (1995) From observation to experimentation: lessons from the past. Eur J Pediatr 154 (Suppl 4):S18-19.

EDITORIAL RETRACTION (2006) Science 311:335.

ENSERINK M (2006) Biomedicine. Selling the stem cell dream. Science 313:160-163.

EVANS M (2011) Discovering pluripotency: 30 years of mouse embryonic stem cells. Nat Rev Mol Cell Biol. 12:680-686.

EZQUER F, EZQUER M, SIMON V, CONGET P (2011) The antidiabetic effect of MSCs is not impaired by insulin prophylaxis and is not improved by a second dose of cells. PLoS One. 6(1):e16566.

FRENCH AJ, ADAMS CA, ANDERSON LS, KITCHEN JR, HUGHES MR, WOOD SH (2008) Development of human cloned blastocysts following somatic cell nuclear transfer with adult fibroblasts. Stem Cells 26:485493.

GILBERT, S. (2006) Fertilization: Beginning of a new organism. In "Developmental Biology" 8th Edition Sinauer Associates Inc. Chapter 7, 175-210.

GINIS I, RAO MS (2003) Toward cell replacement therapy: promises and caveats. Exp Neurol 184:61-77.

GÓMEZ-LOBO A (2004) On the ethical evaluation of stem cell research: remarks on a paper by N. Knoepffler. Kennedy Inst Ethics J 14:75-80.

GUNTER KC, CAPLAN AL, MASON C, SALZMAN R, JANSSEN WE, NICHOLS K, BOUZAS LF, LANZA F, LEVINE BL, RASKO JE, SHIMOSAKA A, HORWITZ E (2010) Cell therapy medical tourism: time for action. Cytotherapy 12:965-968.

HAECKEL E (1912) The Evolution of Man vol. 1 (Watts \& CO, Ed London), pp. 53-54, Online version Project Gutenberg eBooks http:/ / www.gutenberg. org/etext/8700 (access July 26, 2012)

HAYWARD CJ, FRADETTE J, GALBRAITH T, RÉMY M, GUIGNARD R, GAUVIN R, GERMAIN L, AUGER FA. (2012). Harvesting the Potential of the Human Umbilical Cord: Isolation and Characterisation of Four Cell Types for Tissue Engineering Applications. Cells Tissues Organs. [Epub ahead of print] Sep 5

HURLBUT WB, GEORGE RP, GROMPE M (2006) Seeking consensus: a clarification and defense of altered nuclear transfer. The Hastings Center Report 36:42-50.

HWANG WS, ROH SI, LEE BC, KANG SK, KWON DK, KIM S, KIM SJ, PARK SW, KWON HS, LEE CK, LEE JB, KIM JM, AHN C, PAEK SH, CHANG SS, KOO JJ, YOON HS, HWANG JH, HWANG YY, PARK YS, OH SK, KIM HS, PARK JH, MOON SY, SCHATTEN G (2005) Patientspecific embryonic stem cells derived from human SCNT blastocysts. Science 308:1777-1783.

HWANG WS, RYU YJ, PARK JH, PARK ES, LEE EG, KOO JM, JEON HY, LEE BC, KANG SK, KIM SJ, AHN C, HWANG JH, PARK KY, CIBELLI JB, MOON SY (2004) Evidence of a pluripotent human embryonic stem cell line derived from a cloned blastocyst. Science 303:1669-1674.

HYUN I (2010) Allowing innovative stem cell-based therapies beyond clinical trials: ethical and policy challenges. J Law Med Ethics 38:277285.

HYUN I (2010) The bioethics of stem cell research and therapy. J Clin Invest 120:71-75.

HYUN I, LINDVALL O, AHRLUND-RICHTER L, CATTANEO E, CAVAZZANA-CALVO M, COSSU G ET AL (2008) New ISSCR guidelines underscore major principles for responsible translational stem cell research. Cell Stem Cell Commentary 3:607-609.

TAKAHASHI K, YAMANAKA S. (2006) Induction of pluripotent stem cells from mouse embryonic and adult fibroblast cultures by defined factors. Cell 126:663-676.

JAMES S, LANMAN JT (1976) History of oxygen therapy and retrolental fibroplasia. Prepared by the American Academy of Pediatrics, Committee on Fetus and Newborn with the collaboration of special consultants. Pediatrics 57(suppl 2):591-642.

JAWAD S, AL-YASSIN A, HERRIDGE D, LAI WK, ROZARIO N, HENDY J (2012) Safeguarding patients against stem cell tourism. Br J Gen Pract 62:269-670.

KIATPONGSAN S, SIPP D (2009) Medicine. Monitoring and regulating offshore stem cell clinics. Science 323:1564-1565.

KIM YS, CHUNG DI, CHOI H, BAEK W, KIM HY, HEO SH, CHANG DI, NA HR, KIM SH, KOH SH (2012) Fantasies About Stem Cell Therapy in Chronic Ischemic Stroke Patients. Stem Cells Dev. [Epub ahead of print] Aug 6.

KNOEPFFLER N (2004) Stem cell research: an ethical evaluation of policy options. Kennedy Inst Ethics J 14:55-74

LANOSZKA A (2003) The Global Politics of Intellectual Property Rights and Pharmaceutical Drug Policies in Developing Countries. International Political Science Review 24:181-197. 
LAT I, MICEK S, JANZEN J, COHEN H, OLSEN K, HAAS C (2011) Off-label medication use in adult critical care. J Crit Care 26:89-94.

LAU D, OGBOGU U, TAYLOR B, STAFINSKI T, MENON D, CAULFIELD T (2008) Stem cell clinics online: the direct-to-consumer portrayal of stem cell medicine. Cell Stem Cell 3:591-594

LINDVALL O, HYUN I (2009) Medical innovation versus stem cell tourism. Science 324:1664-1665.

LIU ZC, CHANG TM (2006) Transdifferentiation of bioencapsulated bone marrow cells into hepatocyte-like cells in the $90 \%$ hepatectomized rat model. Liver Transpl 12:566-572.

LO B, KRIEGSTEIN A, GRADY D (2008) Clinical trials in stem cell transplantation: guidelines for scientific and ethical review. Clin Trials 5:517-522.

LO B, PARHAM L (2009) Ethical issues in stem cell research. Endocr Rev 30:204-213.

LUNT N, CARRERA P (2010) Medical tourism: assessing the evidence on treatment abroad. Maturitas 66:27-32.

MACREADY N (2009) The murky ethics of stem-cell tourism. Lancet Oncol 10:317-318.

MAINIL T, VAN LOON F, DINNIE K, BOTTERILL D, PLATENKAMP V, MEULEMANS H (2012) Transnational health care: From a global terminology towards transnational health region development. Health Policy. [Epub ahead of print ] Aug 29.

MARTELL K, TROUNSON A, BAUM E (2010) Stem cell therapies in clinical trials: workshop on best practices and the need for harmonization. Cell Stem Cell 7:451-454.

MASON C, MANZOTTI E (2010) Stem cell nations working together for a stem cell world. Regen Med. 5(1):1-4.

MASTER Z, RESNIK DB (2011) Stem-cell tourism and scientific responsibility. Stem-cell researchers are in a unique position to curb the problem of stem-cell tourism. EMBO Rep. 12:992-995.

MCCULLOCH P, ALTMAN DG, CAMPBELL WB, FLUM DR, ET AL. (2009) No surgical innovation without evaluation: the IDEAL recommendations. Lancet 374:1105-1112.

MCMAHON D, THORSTEINSDÓTTIR H (2010a). Regulations are needed for stem cell tourism: insights from China. H. Am J Bioeth10:34-36.

MCMAHON D, THORSTEINSDÓTTIR H (2010b) Lost in translation: China's struggle to develop appropriate stem cell regulations. Scripted 2:283.

MEADOWS M (2001) Promoting safe and effective drugs for 100 years. FDA Consum 40:14-20.

MEISSNER A, JAENISCH R (2006) Generation of nuclear transfer-derived pluripotent ES cells from cloned Cdx2-deficient blastocysts. Nature 439: 212-215.

MELLO MM, BRENNAN TA. (2001) The Controversy Over High-Dose Chemotherapy with Autologous Bone Marrow Transplant for Breast Cancer. Health Affairs 20:101-117.

MERUANE MA, ROJAS M, MARCELAIN K (2012) The Use of Adipose Tissue-Derived Stem Cells within a Dermal Substitute Improves Skin Regeneration by Increasing Neoangiogenesis and Collagen Synthesis. Plast Reconstr Surg 130:53-63.

MINGUEL JJ, ERICES A (2006) Mesenchymal stem cells and the treatment of cardiac disease. Exp Biol Med 231:39-49

MURDOCH CE, SCOTT CT (2010) Stem cell tourism and the power of hope. Am J Bioeth 10:16-23.

NATURE EDITORIAL (2010) Stem-cell laws in China fall short. Nature Edit 467:633.

NELSON B (2008) Stem cell researchers face down stem cell tourism. Nature Reports Stem Cells Published online: 5 June.

NORAMBUENA GA, KHOURY M, JORGENSEN C (2012) Mesenchymal stem cells in osteoarticular pediatric diseases: an update. Pediatr Res. 71:452-458.

OKIE S. (2006) Access before approval-a right to take experimental drugs? N Engl J Med 355:437-440.

ONISTO M, ANANIAN V, CAENAZZO L (2011) Biobanks between common good and private interest: the example of umbilical cord blood private biobanks Recent Pat DNA Gene Seq. 5:166-168.

PEDDIE VL, PORTER M, COUNSELL C, CAIE L, PEARSON D, BHATTACHARYA S (2009) 'Not taken in by media hype': how potential donors, recipients and members of the general public perceive stem cell research. Hum Reprod 24:1106-1113.

PEPPER MS (2010) Cell-based therapy - navigating troubled waters. S Afr Med J. 100(5):286-288.

PERRY AR, LINCH DC (1996) The history of bone marrow transplantation. Blood Rev. 10, 215-219.

PIETRONAVE S, PRAT M (2012) Advances and applications of induced pluripotent stem cells. Can J Physiol Pharmacol 90:317-325.
POURNASR B, KHALOUGHI K, SALEKDEH GH, TOTONCHI M, SHAHBAZI E, BAHARVAND H (2011) Concise review: alchemy of biology: generating desired cell types from abundant and accessible cells. Stem Cells 29:1933-1941.

PRATT B, LOFF B (2011). Justice in international clinical research. Dev World Bioeth 11:75-81.

RADLEY DC, FINKELSTEIN SN, STAFFORD RS (2006) Off-label prescribing among office-based physicians. Arch Intern Med 166:1021-1026.

RAMA P, MATUSKA S, PAGANONI G, SPINELLI A, DE LUCA M, PELLEGRINI G (2010) Limbal Stem-Cell Therapy and Long-Term Corneal Regeneration N Engl J Med 363:147-155.

RAO M, MAUREEN, CONDIC LM (2008) Alternative Sources of Pluripotent Stem Cells: Scientific Solutions to an Ethical Dilemma. Stem Cells Development 17:1-10.

RAO M, AHRLUND-RICHTER L, KAUFMAN DS (2012) Concise review: Cord blood banking, transplantation and induced pluripotent stem cell: success and opportunities. Stem Cells 30:55-60.

REVAZOVA ES, TUROVETS NA, KOCHETKOVA OD ET AL (2007) Patientspecific stem cell lines derived from human parthenogenetic blastocysts. Cloning Stem Cells 9:432-449.

REVAZOVA ES, TUROVETS NA, KOCHETKOVA OD ET AL (2008) HLA Homozygous Stem Cell Lines Derived from Human Parthenogenetic Blastocysts. Cloning Stem Cells 10:11-24.

RIAZI AM, KWON SY, STANFORD WL (2009) Stem cell sources for regenerative medicine. Methods Mol Biol 482:55-90.

ROSENECKER J (2010) The long and winding road to clinical success in gene therapy. Curr Opin Mol Ther 12:507-508.

RYAN JM, PETTIT AR, GUILLOT PV, CHAN JK, FISK NM (2011) Unravelling the Pluripotency Paradox in Fetal and Placental Mesenchymal Stem Cells: Oct-4 Expression and the Case of the Emperor's New Clothes. Stem Cell Rev [Epub ahead of print] Dec 11

RYAN KA, SANDERS AN, WANG DD, LEVINE AD (2010) Tracking the rise of stem cell tourism. Regen Med 5:27-33.

SAMUEL GN, KERRIDGE IH, O'BRIEN TA (2008) Umbilical cord blood banking: public good or private benefit? Med J Aust 188:533-535.

SANTOS JM, VENTURA-JUNCÁ P (2009) El inicio de la vida de un nuevo ser humano. Ars Médica 18: 33-43.

SCHUIJERS J, CLEVERS H (2012) Adult mammalian stem cells: the role of Wnt, Lgr5 and R-spondins. EMBO J 31:2685-2696.

SCHWARTZ SD, HUBSCHMAN JP, HEILWELL G, FRANCO-CÁRDENAS V, PAN CK, OSTRICK RM, MICKUNAS E, GAY R, KLIMANSKAYA I, LANZA R (2012) Embryonic stem cell trials for macular degeneration: a preliminary report. Lancet Published online January 23,

SHALEV C (2010) Stem cell tourism--a challenge for trans-national governance. Am J Bioeth 10:40-42.

SHOEMAKER D (2010) Personal identity and bioethics: the state of the art Theor Med Bioeth 31:249-257.

SIMON BM, MURDOCH CE, SCOTT CT (2010) Pluripotent patents make prime time: an analysis of the emerging landscape. Nat Biotechnol 28:557-559.

SIPP D (2011) Stem cell stratagems in alternative medicine. Regen Med. 6:407-414.

SMITH FO (2011) Why do parents engage in private cord blood banking: Fear, realistic hope or a sense of control? Pediatr Blood Cancer 56:10031004.

SOLER B, FADIC R, VON BERNHARDI R (2011) Stem cells therapy in amyotrophic lateral sclerosis treatment. A critical view. Rev Neurol 52:426-434.

SUGARMAN J (2008) Human stem cell ethics: beyond the embryo. Cell Stem Cell 2:529-533.

TAYLOR PL, BARKER RA, BLUME KG, CATTANEO E (2010) Patients beware: commercialized stem cell treatments on the web. Cell Stem Cell 7:43-49.

THIRABANJASAK D, TANTIWONGSE K, THORNER PS (2010) Angiomyeloproliferative lesions following autologous stem cell therapy. J Am Soc Nephrol 21:1218-1222.

THOMAS ED (2005) Bone marrow transplantation from the personal viewpoint. Int J Hematol 81:89-93.

TUFFS A (2010) Stem cell treatment in Germany is under scrutiny after child's death. Brit Med J 341:c6203.

VALENZUELA CY (2007). On the ontogenetic origin of human beings: the scientific solution. Rev Med Chile 135(1):121-126.

VENTURA-JUNCÁ P, SANTOS MJ (2011) The beginning of life of a new human being from the scientific biological perspective and its bioethical implications. Biol Res 44:201-207. 
VENTURA-JUNCÁ P., SANTOS M., LARRAÍN J (2009) Proposals for Embryonic Stem Cell production without destroying Human Embryos: scientific and bioethical challenges. Acta Bioethica 15:222-233.

VERMA IM (1994) Gene therapy: hopes, hypes, and hurdles. Mol Med. $1(1): 2-3$

VIERBUCHEN T, OSTERMEIER A, PANG ZP, KOKUBU Y, SÜDHOF TC, WERNIG M (2010) Direct conversion of fibroblasts to functional neurons by defined factors. Nature 463:1035-1041.

WELLS WT (1984) Warnock report on human fertilisation and embryology. Lancet 2(8401):531-532
WHITE PAPER (2005): Alternative sources of human pluripotent stem cells Washington, D.C.: The President's Council on Bioethics.

YANG L (2011) From fibroblast cells to cardiomyocytes: direct lineage reprogramming. Stem Cell Res Ther 2:1.

ZARZECZNY A, CAULFIELD T (2009) Emerging ethical, legal and social issues associated with stem cell research \& and the current role of the moral status of the embryo. Stem Cell Rev 5:96-101.

ZARZECZNY A, RACHUL C, NISBET M, CAULFIELD T (2010) Stem cell clinics in the news. Nat Biotechnol 28:1243-1246. 

